\title{
National Strategies and Practices in Internationalisation of Higher Education: Lessons from a Cross-Country Comparison
}

\author{
Liviu Matei and Julia Iwinska
}

Keywords National internationalization strategy - Higher education system • Comparative higher education - International student recruitment

\section{Introduction}

Internationalisation is not a new or overlooked phenomenon in higher education. For over two decades by now it has attracted increasing attention both in the policy arena, at institutional, national, or international level, as well as in the scholarly literature on higher education policy (Knight 1999; Kehm 2003; Altbach and Knight 2007; Kehm and Teichler 2007; Teichler 2012). Internationalisation of higher education is a global phenomenon affecting all countries of the world. There are considerable differences, however, across countries in what drives the process, how important it is deemed, how it is understood and managed, or what the expected outcomes are. The understanding of the concept of internationalisation remains diverse also among the various higher education stakeholders. Many view it as equivalent to international student mobility. Others look beyond student mobility and mobility programmes (like the Erasmus programme in Europe) and see the process as much more complex, which includes activities such as building international communication networks in higher education, building and expansion of international cooperation networks (for example in research), internationalisation of curricula, establishing international joint degree programs, staff mobility, and, more recently, opening branch campuses abroad, or 'virtual mobility'. The rationales behind various institutional-level efforts, or broader system-level approaches to internationalisation can also differ. National policy makers in different countries

L. Matei $(\bowtie) \cdot$ J. Iwinska

Central European University, Budapest, Hungary

e-mail: mateil@ceu.hu

J. Iwinska

e-mail: iwinskaj@ceu.hu

(C) The Author(s) 2015

A. Curaj et al. (eds.), Higher Education Reforms in Romania,

DOI 10.1007/978-3-319-08054-3_11 
can be selectively motivated by one or a combination of reasons, usually including: national competitiveness and economic development, geopolitical aspects, or demographic concerns. Institutional leaders, on the other hand, might be more interested in the opportunities of bringing new talent from abroad to their institutions, joining international research networks or in generating additional income for their institutions.

One important question that could be asked in this context is whether the existence of a national strategy for internationalisation has a positive impact or whether such a strategy is even at all necessary? Some may argue that it could be more efficient if it was left to the higher education institutions (HEIs) themselves to decide what to do. It appears, however, that the currently favoured model for advancing internationalisation in Europe, which is also promoted by the European Commission, calls for more centralised and comprehensive strategic approaches, which should address both broader national priorities and institutional interests. (European Commission 2013; Kehm and Teichler 2007). As suggested by the responses from 175 higher education institutions across 38 countries to a recent survey on internationalisation conducted by the European University Association (EUA), having an EU-level internationalisation strategy could further stimulate development of national strategies, which in turn would have positive effects on the institutional efforts in this area, and would attract the much needed public attention to the topic in general (EUA 2013). Having a well-defined and coherent strategy on the national level is also mentioned as an important factor for advancing internationalisation efforts in a study published by the British Council (2011). Other than simply having an internationalisation strategy at national level, it has also been argued that in order for such strategy to be effective it should be broad in its scope and closely connected with other national priority areas including economic development, science and technology, migration and trade (ibid).

Taking note of the diversity of internationalisation approaches that exist in Europe at present, the article seeks to analyse and compare system level settings in four countries. Specifically, it looks at Poland, Germany, Estonia and Romania, which appear to be at different stages with regard to their overall internationalisation efforts and strategy development. The article aims not only to compare formal internationalisation strategies, where they exist, but also to analyse alternative approaches and mechanisms at work where a government-level, or national strategy is missing. Furthermore, the article outlines and compares key aspects of strategies or strategic approaches, such as: the actors involved in and driving the internationalisation process, the key elements of the strategies, the goals and targets set nationally, the support structures and resources.

The research is based primarily on the analysis of national policy documents, such as internationalisation strategies, national strategies for higher education or national migration strategies, as well as on research articles on higher education policies and on internationalisation. We note that at this stage not much data is available on the impact assessment of national-level internationalisation strategies.

In addition to simply presenting findings from the four-country comparison, the article also raises broader questions regarding the role a national strategy for 
internationalisation of higher education can or should play, what aspects and stakeholders such a strategy might involve, as well as what alternative approaches can be used instead of a formal national strategy. The study's conclusions raise questions and provides some preliminary rather than final answers about what might work better in terms of internationalisation strategies and practices for a country like Romania.

In this way, the article aims primarily to contribute to the ongoing debate on higher education in Romania, to the process of development of a national strategy for higher education in this country (currently missing), and in particular to the debate about a national internationalisation strategy for higher education.

\section{The European Context}

The European Commission (EC), in its recent Communication on "European higher education in the world" (EC 2013), reiterates once again the belief in the importance of internationalisation for Europe, and attempts to put the topic firmly on the agenda for the coming years. The document itself represents a blue-print for a broad internationalisation strategy, which identifies priority areas and strategic directions for the sector at EU/European level. Moreover, this strategy is expected to be supported by funds secured under the EU multiannual financial framework 2014-20, in particular by part of the over EUR 14 billion that will be allocated to the ERASMUS+ programme. By presenting an internationalisation strategy for European higher education, the Commission not only calls the universities "to think global" but it also emphasises the importance of having such strategies on the national system level. Following on previous documents from the European Union institutions, in particular on the series of communications on the modernisation of higher education (EC 2003, 2006, 2011), the 2013 Communication is meant as a guiding tool for the Member States to help them develop their own customised approaches to internationalisation, and the Commission assures of its readiness to assist in that process (EC 2013).

In Europe, the number of countries that have comprehensive internationalisation strategies for higher education does not seem too high at present. There are several countries, however, like Germany, which have comprehensive, almost "allencompassing" formal strategies in place, and are well on the way or in the process of implementing them on various levels. Interestingly, there are also countries that have well-articulated internationalisation strategies, like Estonia, but they seem to be focused on particular aspects of internationalisation, rather than adopting a comprehensive approach. Estonia, to continue with one of our case studies, focuses on international student recruitment, and more specifically recruitment of master and doctoral students. There are other countries that promote targeted international student recruitment strategies on the national level as their model of an internationalisation strategy for higher education. For more information on this topic and for more examples, one could refer to a study by the Netherlands Organisation for 
International Cooperation's (Nuffic) on national government policies in the area of international student recruitment and student mobility covering 11 countries including the Netherlands, UK, Germany, Switzerland and France from Europe. ${ }^{1}$ The target audience, as stated in the report, was the Dutch policy makers and recruiters at national and institutional levels, who can use the collected data exactly in the process of development of international student recruitment strategies and policies (Becker and Kolster 2012).

Other countries in Europe, including some of the "new" EU Member States, are in less advanced stages of development of any kind of national strategies in higher education, including regarding internationalisation. Romania, for example, is only starting the process to develop a comprehensive national strategy for higher education, which will eventually incorporate a separate sub-strategy for internationalisation. It is our understanding, based on private reports, that the process is currently at the stage of technical consultations with international experts. We have not been able to access any documents about this process. Slovakia also does not have a strategy in place at present but, as we have learnt informally from a local higher education expert, it is also planning to develop one in the near future. On the other hand, in Poland, bottom-up approaches driven by the Rectors' Conference in cooperation with a non-governmental organisation and local authorities are more visible than government-level activities (Siwinska 2009).

To conclude this section, the recommendation for more comprehensive, national strategies for internationalisation, as encouraged by the Commission, certainly invites a closer examination of the existing system-level approaches in Europe, how they are constructed (when they exist), and also how they work in practice. The present study is a non-exhaustive attempt at providing preliminary information for such an examination.

\section{What Is a Good Internationalisation Strategy in Europe?}

The European Commission's view on what a good national strategy for internationalisation of higher education can be inferred from the Communication mentioned above (EC 2013) and preceding documents. The EC endorses a cross-sector approach, indicating that an internationalisation strategy for higher education should be coordinated with and support the relevant national polices for external cooperation, international development, migration, trade, employment, regional development and research and innovation. Other authoritative actors in internationalisation elaborate along the same lines, adding, for example, that a welldeveloped internationalisation strategy is typically led by the relevant ministry and if possible captures broader policy goals (British Council 2011). Among the various

\footnotetext{
${ }^{1}$ Other countries analysed in the study were: the United States, Canada, Australia, Singapore, Malaysia and China. .
} 
recommendations in this area put forward by authoritative sources, the focus on the coordination with the other policy areas such as migration, trade and economic development, research, science, and technology are highlighted as particularly relevant and important for national higher education internationalisation strategies in Europe. In our own study, it appears that only one country, Germany, lives up to these expectations, while another one, Estonia, appears to aim at reaching similarly ambitious goals by a more selective, strategic approach. The other two countries, Poland and Romania, appear to be quite far, or very far, respectively, from meeting such high standards.

The European Commission further states that a national internationalisation strategy should be developed individually and customised based on each country's unique set of circumstances rather than in the "one-size-fits-all" spirit (EC 2013). However, in this Communication about European higher education in the world, the Commission also provides quite detailed guidelines for the Member States regarding which common key areas to include when developing individual national internationalisation approaches for higher education. This could eventually help harmonise efforts across Europe. The three pillars that are considered key for internationalisation strategies in Europe, but should still be customised within national frameworks, are:

- international student and staff mobility;

- the internationalisation and improvement of curricula and digital learning;

- and strategic cooperation, partnerships and capacity building.

The Organisation for Economic Cooperation and Development (OECD) analyses national approaches to internationalisation of higher education from a different angle. In its 2004 report "Trade in Higher Education: Opportunities and Challenges", four types of approaches are identified based on the rationales and motivations/needs driving different national strategies (OECD 2004, see Table 1). For each approach, a set of internationalisation tools can be identified. For example, efforts focusing on fee-paying international student recruitment point to the "revenue-generating approach", according to this classification. The introduction of government-funded scholarships for targeted fields of study represents most likely an interest in the skilled migration approach. The respective approaches are not mutually exclusive and typically can complement each other within one broader strategy, depending on the country's circumstances and priorities. The OECD

Table 1 Types of approaches to cross-border post-secondary education (OECD 2004)

\begin{tabular}{l|l}
\hline I. & $\begin{array}{l}\text { The mutual understanding approach encompasses political, cultural, academic and } \\
\text { development aid goals }\end{array}$ \\
\hline II. & The skilled migration approach \\
\hline III. & The revenue-generating approach \\
\hline IV. & $\begin{array}{l}\text { The capacity building approach encourages the use of foreign post-secondary education, } \\
\text { however delivered, as a quick way to build an emerging country's capacity. }\end{array}$ \\
\hline
\end{tabular}

Source OECD. 2004. Trade in Higher Education: Opportunities and Challenges 
taxonomy is a simple and useful heuristic tool in analysing and understating various approaches to internationalisation as well as their links to other policy areas. It also indicates that combining several ways of looking at internationalisation strategies and their specific elements could possibly be a helpful guideline for the policy makers in Europe, including in Romania.

\section{Cross-Country Comparison}

The four countries included in the analysis, Poland, Estonia, Germany and Romania, represent different approaches and level of advancement in their internationalisation efforts on the system level. They are also different in the size of their higher education populations (student and staff). To give an indication regarding the sizes of the respective national higher education systems, Estonia had slightly less than 100,000 students in 2012, Poland had slightly less than 2 million, Germany had slightly more than 2 million, while Romania went below 1 million (it exceeded this number a few years ago, then student enrolment went down).

A series of tables organized thematically will be used below to summarize and help interpret the differences. The differences are indeed important and, quite remarkably, they become easily detectable at a simple visual inspection of the tables, even before detailing the substance of the situation in each country. The spread of choices and practices in different countries is quite significant as well, which is helpful for the policy reflection in countries like Romania, which has the chance to build a new approach basically from scratch.

\subsection{Presence (or Lack) of a National Internationalisation Strategy. Key Elements of National Internationalisation Strategies or Key Practices/Activities}

A synopsis regarding the existence (or lack of) of national strategies and approaches, and the key documents in which these strategies and approaches are elaborated is presented in Table 2, below, followed by a detailed discussion. Table 3 provides a summary of the key elements of either strategies or practices with regard to internationalisation in the countries analysed. Furthermore, Table 3 succinctly illustrates the main targets we have been able to identify in the national formal strategies or de facto national approaches to internationalisation.

When looking for the presence of a well-developed strategy on the national level, only Germany and Estonia satisfy this condition in our group of countries. Germany has a long history of internationalisation and international academic cooperation, and is one of the top destinations worldwide for international students; in $2011,6 \%$ of the total number of international students came to study in Germany 
Table 2 System-level internationalisation strategies and approaches; main documents in which they are elaborated

\begin{tabular}{|c|c|c|c|}
\hline Poland & Estonia & Germany & Romania \\
\hline $\begin{array}{l}\text { Lack of unified } \\
\text { formal strategy at } \\
\text { system level } \\
\text { Bottom-up } \\
\text { approaches } \\
\text { coordinated by } \\
\text { Rectors' } \\
\text { Conference in } \\
\text { cooperation with a } \\
\text { non-governmental } \\
\text { agency and, in } \\
\text { some cases, local } \\
\text { authorities } \\
\text { Poland's Migration } \\
\text { Policy (2012) - } \\
\text { partially deals with } \\
\text { status of } \\
\text { international } \\
\text { students, } \\
\text { researchers, etc }\end{array}$ & $\begin{array}{l}\text { Formal, well- } \\
\text { articulated strategy, } \\
\text { elaborated in a series } \\
\text { of recent documents } \\
\text { Internationalization } \\
\text { Strategy 2006-2015; } \\
\text { Agreement on } \\
\text { Good Practice in } \\
\text { Internationalization } \\
\text { of Estonia's HEIs } \\
\text { (Rectors' } \\
\text { Conference, Ministry } \\
\text { of Education \& } \\
\text { Research, } \\
\text { Archimedes } \\
\text { Foundation); } \\
\text { Other documents: } \\
\text { Estonian HE } \\
\text { Strategy 2006-2015 } \\
\text { Estonian Research, } \\
\text { Development and } \\
\text { Innovation Strategy } \\
\text { 2007-2013 }\end{array}$ & $\begin{array}{l}\text { Numerous strategies } \\
\text { in place since 1990s, } \\
\text { well-articulated and } \\
\text { coordinated, also } \\
\text { across sectors and } \\
\text { levels, based on and } \\
\text { presented in formal } \\
\text { documents } \\
\text { Latest: } \\
\text { DAAD Strategy } \\
2020 \text { (2013); } \\
\text { Strategy of the } \\
\text { Federal and Länder } \\
\text { Ministers of Science } \\
\text { for the } \\
\text { Internationalisation } \\
\text { of the Higher } \\
\text { Education } \\
\text { Institutions in } \\
\text { Germany (2013); } \\
\text { Strategy of the } \\
\text { Federal Government } \\
\text { for the } \\
\text { Internationalization } \\
\text { of Science and } \\
\text { Research (2008) }\end{array}$ & $\begin{array}{l}\text { Lack of unified } \\
\text { formal strategy at } \\
\text { system level; } \\
\text { scattered reference in } \\
\text { various documents. } \\
\text { Existing practices } \\
\text { driven mainly by } \\
\text { European/Bologna } \\
\text { processes and } \\
\text { bilateral agreements. } \\
\text { No nationally-driven } \\
\text { approaches, except } \\
\text { towards Moldova }\end{array}$ \\
\hline
\end{tabular}

(OECD 2013). Moreover, a recent research commissioned by the British Council ranked Germany as number one among 11 countries for its overall internationalisation-friendly national policy environment, taking into consideration factors such as openness, quality assurance, degree recognition, as well as access and equity (British Council 2011).

It is not a surprise for Germany to be the leader among the countries compared here since it is also one of the leaders globally. The prominent German Academic Exchange Service (DAAD) has been active and well-funded since the 1950s in promoting international academic cooperation, and in particular exchange of students and scholars. Germany has also had various internationalisation strategies already since the 1990s (see the Germany chapter by N. Rohde in Ferencz and Wächter 2012). The most recently developed national-level key strategic documents supporting internationalisation are: a joint Strategy of the Federal and Länder Ministers of Science for the Internationalisation of the Higher Education Institutions in Germany (2013), the DAAD 2020 Strategy (2013a, b), and Strengthening Germany's Role in the Global Knowledge Society. Strategy of the Federal Government for the Internationalization of Science and Research (2008). 
Table 3 Synopsis of key elements of national internationalisation strategies, or key practices/ activities

\begin{tabular}{|c|c|c|c|}
\hline Poland & Estonia & Germany & Romania \\
\hline Key activities: & $\begin{array}{l}\text { Focus on attracting } \\
\text { MA and PhD-level } \\
\text { students; scholarships } \\
\text { for international MA } \\
\text { and PhD students }\end{array}$ & $\begin{array}{l}9 \text { fields of action } \\
\text { (second systematic } \\
\text { phase according to } \\
\text { Teichler 2007) }\end{array}$ & $\begin{array}{l}\text { Participation } \\
\text { in bilateral } \\
\text { and } \\
\text { multilateral } \\
\text { agreements }\end{array}$ \\
\hline \multirow[t]{2}{*}{$\begin{array}{l}\text { Bottom-up, HEIs- } \\
\text { driven efforts to recruit } \\
\text { international students: }\end{array}$} & & $\begin{array}{l}\text { 1. Strategic } \\
\text { internationalisation of } \\
\text { HEIs }\end{array}$ & \\
\hline & & $\begin{array}{l}\text { 2. Improving the legal } \\
\text { framework for } \\
\text { internationalisation }\end{array}$ & $\begin{array}{l}\text { Special } \\
\text { scholarship } \\
\text { program for } \\
\text { students from } \\
\text { Moldova }\end{array}$ \\
\hline \multirow{4}{*}{$\begin{array}{l}\text { Marketing campaign } \\
\text { "Study in Poland" ( } 43 \\
\text { HEIs participating) } \\
\text { between } 2005 \text { and } \\
\text { 2012: participation in } \\
\text { international fairs; } \\
\text { individual presentations } \\
\text { of Polish universities } \\
\text { abroad; joint web portal }\end{array}$} & $\begin{array}{l}\text { Creation of a } \\
\text { supportive legal } \\
\text { environment; }\end{array}$ & $\begin{array}{l}\text { 3. Establishing a } \\
\text { culture of welcome }\end{array}$ & \\
\hline & & $\begin{array}{l}\text { 4. Establishing an } \\
\text { international campus }\end{array}$ & \\
\hline & $\begin{array}{l}\text { Internationalisation of } \\
\text { teaching: programs in } \\
\text { English. }\end{array}$ & $\begin{array}{l}\text { 5. Increasing } \\
\text { international mobility } \\
\text { of students }\end{array}$ & \\
\hline & & $\begin{array}{l}\text { 6. Enhancing } \\
\text { Germany's } \\
\text { attractiveness as a } \\
\text { place to study }\end{array}$ & \\
\hline \multirow{3}{*}{$\begin{array}{l}\text { Study in Warsaw, } \\
\text { Study in Krakow } \\
\text { initiatives, in } \\
\text { cooperation with local } \\
\text { authorities. }\end{array}$} & $\begin{array}{l}\text { Development of a } \\
\text { support system for } \\
\text { internationalisation. }\end{array}$ & $\begin{array}{l}\text { 7. Attracting excellent } \\
\text { (young) academics } \\
\text { from abroad }\end{array}$ & \\
\hline & & $\begin{array}{l}\text { 8. Expanding } \\
\text { international research } \\
\text { cooperation }\end{array}$ & \\
\hline & & $\begin{array}{l}\text { 9. Establishing } \\
\text { transnational courses }\end{array}$ & \\
\hline $\begin{array}{l}\text { Development of } \\
\text { internationalisation } \\
\text { strategies on individual } \\
\text { HEI level }\end{array}$ & & $\begin{array}{l}\text { Other activities and } \\
\text { strategic provisions: } \\
\text { umbrella marketing } \\
\text { campaigns ("Study in }\end{array}$ & \\
\hline
\end{tabular}


Table 3 (continued)

\begin{tabular}{|c|c|c|c|}
\hline Poland & Estonia & Germany & Romania \\
\hline & & $\begin{array}{l}\text { Germany"; "Research } \\
\text { in Germany") } \\
\text { new Immigration } \\
\text { Law since } 2005 \\
\text { improvements in } \\
\text { recognition of foreign } \\
\text { degrees. }\end{array}$ & \\
\hline \multicolumn{4}{|l|}{$\begin{array}{l}\text { HEIs use specially } \\
\text { designed iPhone, and } \\
\text { iPad apps to attract } \\
\text { international students }\end{array}$} \\
\hline $\begin{array}{l}\text { Targeting foreign } \\
\text { students of Polish } \\
\text { origin (with } \\
\text { government } \\
\text { scholarships) }\end{array}$ & & $\begin{array}{l}\text { DAAD } 2020 \text { strategy: } \\
\text { Scholarships for the } \\
\text { best } \\
\text { Outward-looking } \\
\text { structures (helping } \\
\text { HEIs realize their } \\
\text { strategies) - Promote } \\
\text { expertise for scientific } \\
\text { and academic } \\
\text { cooperation }\end{array}$ & \\
\hline $\begin{array}{l}\text { Ukraine designated as } \\
\text { a target country. }\end{array}$ & & & \\
\hline
\end{tabular}

Germany has a very well-elaborated, comprehensive strategy for internationalisation, coordinated across sectors and also across levels of policy making and implementation, as illustrated in Table 3 below (Germany's column is always the thickest in any of these tables!). The combined federal and state (Länder) strategy identifies nine concrete fields of action supporting internationalisation with joint policy goals for each field. The nine areas effectively combine priorities of all stakeholders, from individual higher education institutions to the German states (Länder), and up to the overarching national level. The fields of action range from very concrete ones (such as "strategic internationalisation of the individual HEIs"), to broader goals aiming at improvements of the legal structures to support internationalisation at the national and Länder levels, and to even broader national aims such development of a "culture of welcome". The DAAD's strategic priorities until 2020 work well with the system level fields of action and cover three main areas, such as merit-based scholarships; support for higher education institutions to help them realise their internationalisation strategies; and expert advice in the area of scientific and academic cooperation (DAAD 2013a, b).

Estonia is an interesting case as another country that actually does have a formal strategy for internationalisation of higher education at the national level since 2006, the Estonian Higher Education Internationalisation Strategy 2006-2015 (Study in Estonia website). The strategy is complemented by The Agreement on Good 
Practice in the Internationalisation of Estonia's Higher Education Institutions, which is a joint document signed by the Rectors' Conference, the Ministry of Education and Research and the Archimedes Foundation in 2007, focusing specifically on the issue of quality in internationalisation of higher education. Moreover, similar to Germany, the country has developed additional strategic documents such as the Estonian Higher Education Strategy also for the 2006-2015 period, and the Estonian Research Development and Innovation Strategy for 2007-2013.

The Estonian Higher Education Internationalisation Strategy clearly states its objectives, which are to make the system more competitive within the region, to make it more open by creating adequate legal and institutional tools, and to make Estonian higher education more visible internationally. The document is divided into three main strategic areas focusing on: (1) creating supportive legal frameworks; (2) internationalisation of teaching; and (3) support system for internationalisation overall. In addition, the voluntary Agreement on Good Practice in the Internationalisation of Estonia's Higher Education Institutions signed by rectors of public, private and professional institutions focuses on specific aspects relevant to international students but also for international academic staff. The Agreement touches upon many important subjects in the area of internationalisation, including the rights of international students, issues related to admissions, such as language requirements, as well as responsibilities and duties of the higher education institutions to ensure quality education for international students and also a suitable environment for international academic staff. For example, the Agreement specifies that: “(...) participating higher education institutions shall ensure that academic staff involved in the curricula and programmes taught in foreign languages have the necessary linguistic competence in those languages". Or that a "participating higher education institution shall support the adaptation of its international researchers and teaching staff to life in Estonia by facilitating their close interaction with its academic and support staff." (Agreement on Good Practice in the Internationalisation of Estonia's Higher Education Institutions). Some of the changes on the system level, as projected in the strategy, were driven by higher education institutions joining their forces. For example, universities were able to influence changes in the legislative environment, and at present graduating students are allowed to stay in Estonia for 6 months after finishing their studies to work, while previously they had to leave the country right away (ICEF Monitor 2013).

The overall internationalisation efforts in Estonia seem well-coordinated among different stakeholders (see Table 5, below), such as the government actors, and higher education institutions, with the help of the Archimedes Foundation, a nongovernmental organization set up expressly to help implement government strategies and projects in national and international education and research. The Estonian approach is also a strategic one. For example, Estonia identified priority countries (top markets) for its internationalisation efforts and is targeting mostly: Finland, Russia, Latvia, Turkey, and China. The head of Archimedes Communications claims that it was not the just the Internationalisation Strategy but in fact the 
branding and marketing campaign "Study in Estonia" launched in 2008 that really made a difference. (ICEF Monitor 2013).

Despite an OECD recommendation in 2007 or the recent EC recommendations, the higher education system in Poland operates still without a national strategy for internationalisation or a clearly formulated national level approach. Some provisions that apply to international students are included in policy documents about international migration (Poland's Migration Policy 2012). The absence of a national internationalisation strategy, however, does not mean that internationalisation is not important for individual higher education institutions in Poland (as indicated in Table 3, above). On the contrary, universities in collaboration with a non-governmental foundation (Perspektywy Foundation) and, in a very few cases, with local authorities, seem to be the main (and possibly only) driving forces behind the existing internationalisation efforts. Interestingly, the focus of their efforts is also on the international student recruitment (evoking a revenue-generating approach), which is supported by a "Study in Poland" initiative and marketing campaign coordinated by the Perspektywy Foundation. There are 43 universities participating in the "Study in Poland" initiative out of the over 450 institutions in total, including over 100 public higher education institutions. Recently presented achievements of the campaign for years 2005-2012 included participation in 55 international educational fairs, presence in 17 countries worldwide, and development of a joint web portal as well as newly added social media and other new IT tools such as applications for mobile phones to attract international students (Siwinski presentation at conference in Warsaw "Studenci zagraniczni 2013" on 17-18 January 2013). In addition, smaller branding and marketing initiatives of similar kind have emerged on regional levels and out of cooperation of regional governments with higher education institutions. For example, collaborative efforts of Cracow-based universities led to establishment of a "Study in Krakow" campaign (http://www.study-krakow.com/). Similar activities can be found in Lublin, which promotes itself with "Study in Lublin" campaign (http://study.lublin.eu/en/). Not surprisingly, there is also a "Study in Warsaw" campaign and apparently more are being developed in other cities.

The internationalisation approach and activities are fundamentally bottom-up in Poland. Which does not mean that they do not include strategic elements. For example, Ukraine has been designated as a priority target country and special local recruitment offices have been set up across Ukraine as part of the "Study in Poland" program (www.studyinpoland.pl).

Romania does not have a national internationalisation strategy, or any set of coordinated practices, neither top-down nor bottom up (Romania's columns in Tables 2 and 3 are almost empty!). This does not mean that internationalisation activities are completely missing. Where they exist, they are to a large extent a result of Romania's participation in bilateral or international agreements and programmes for student and staff mobility, such as the Erasmus or CEEPUS programmes. Romania also participates in European collaborative research programmes that also facilitate international mobility to some extent. In addition, Romania has a special program, run jointly by the Ministry of Foreign Affairs and 
Ministry of Education to support incoming students from neighbouring Moldova, motivated by cultural, economic, national and geopolitics rationales. Students from Moldova, who speak the same language, in fact represent half of the total "international" students in Romania. We have also noted a few individual efforts by individual universities to attract international fee paying students. They appear to have only very limited success.

We have seen in this section that both Germany and Estonia have strategies at national level for higher education as a whole, and then a separate, but coordinated strategy for internationalisation. Moreover, both countries have formal strategies at national level for research, with which the overall higher education strategy and internationalisation strategy are also coordinated. Even more, all these strategies (higher education, research, and internationalisation) are coordinated with the strategies for other sectors. Germany is actually a model-case, illustrating almost perfectly the ideal model projected by the EC and others, discussed in the first part of the article. Estonia is not far from this model either. It choices are more strategic (or focused, as mentioned earlier), and its strategic planning is more recent. It is also a much smaller population and HE system in comparison to Germany, which might partially explain the more focused strategic approach. Poland and Romania have none of these: neither internationalisation strategy, nor higher education or research strategy, which makes any comment about "coordination" intra-sectoral, or crosssectoral, simply superfluous.

This situation might invite the question whether an internationalisation strategy for higher education, which is our subject, is at all possible without a more complex set strategic policy and planning process which would include higher education as a whole, research, and other areas and sectors (such migration, economic development, demographic policies) or, more generally, a sound and comprehensive strategic policy planning process at national level. Our study does not provide sufficient evidence to answer the question, but it does indicate that it is an important question to consider.

Another informative dimension of comparison among the four countries proves to be that of strategic targets in internationalisation of higher education, whether formal or informal. Findings from the comparison on this dimension contribute to further refining the conclusions about the four countries, in fact contribute to drawing individual country profiles with regard to internationalisation. Moreover, this comparison is informative in assessing both the ambitions and the potential for success in the four countries, although it does not provide a clear-cut answer to the question regarding "what works best". As illustrated in Table 4 (below), there are quite clear targets in Germany, Estonia, and Poland. Romania, on the other side, appears to place itself again in a special territory, with no targets of any kind, at least not for the time being.

It is surprising in a way that Poland is in the category "with targets", since it does not have a formal national tragedy for internationalisation. The target of increasing the number of foreign students in Poland to 100,000 or $5 \%$ of the total student population by 2020 is an informal one, set by HEIs coordinating their internationalisation efforts, as explained above. What is remarkable in the case of Poland is 
Table 4 Strategic targets in internationalisation: formal or informal

\begin{tabular}{|c|c|c|c|}
\hline Poland & Estonia & Germany & Romania \\
\hline $\begin{array}{l}\text { Unofficial target: } \\
100,000 \\
\text { incoming } \\
\text { foreign students } \\
\text { by } 2020\end{array}$ & $\begin{array}{l}\text { Targets for 2015: } \\
\text { increasing number of } \\
\text { international students to } \\
\text { the level of } 2000, \text { mostly } \\
\text { on master and PhD level; } \\
\text { increasing the number of } \\
\text { Estonian students in } \\
\text { exchange programs to the } \\
\text { level of } 2000 ; \\
3 \% \text { of permanent } \\
\text { teaching staff positions are } \\
\text { occupied by foreign } \\
\text { professors; } \\
\text { an opportunity for all } \\
\text { Estonian PhD students to } \\
\text { spend at least one semester } \\
\text { in a foreign university; } \\
10 \% \text { of foreigners among } \\
\text { PhD students and post- } \\
\text { doctoral students in } \\
\text { Estonian universities }\end{array}$ & $\begin{array}{l}\text { E.g.: at least } \\
350,000 \\
\text { foreign } \\
\text { students by } \\
2020\end{array}$ & $\begin{array}{l}\text { No strategy - no stated } \\
\text { targets, except those } \\
\text { resulting from } \\
\text { international commitments } \\
\text { (E.g. as part of Europe } \\
\text { 2020 Strategy) }\end{array}$ \\
\hline $\begin{array}{l}\text { Or } 5 \% \text { of total } \\
\text { student } \\
\text { population by } \\
2020\end{array}$ & & & \\
\hline
\end{tabular}

that the bottom-up, non-government driven mobilisation in internationalisation is quite significant, and although in a way "spontaneous", it is not disorganized or chaotic: these activities benefit from strategic choices made by participating institutions, and are also oriented by clear, although informal targets. We present this characteristic as an important "statement of facts". The question whether or not this "model" is effective, whether it works, remains to be answered.

Estonia's "targets" column appears remarkably precise and also "strategic" (clear and well-reflected upon choices), following directly from the focused nature of the overall internationalisation strategy. It is also quite ambitious, speaking for example of the objective of having $3 \%$ of permanent teaching staff positions occupied by foreign professors by 2015 , or reaching a threshold of $10 \%$ foreigners at doctoral and post-doctoral level.

As expected, Germany has an elaborated set of targets, some of which are already apparent in Tables 2 and 3 above. We have chosen not to list all of them (which make the German column artificially thin this time, a very detailed presentation of targets in the area of student mobility is provided in the Ferencz and Wächter 2012, in the chapter dedicated to Germany), but rather illustrate the scope of German ambitions in internationalisation with one example. The number of foreign students is planned to rise to about 350,000 by 2020 , an increase of about $40 \%$ compared with 2011 (over 250,000 international students, see Table 6). 
Table 5 Key actors in national internationalisation strategy/practices

\begin{tabular}{l|l|l|l}
\hline Poland & Estonia & Germany & Romania \\
\hline Perspektywy & Ministry of & DAAD; Federal & Ministry of \\
Foundation; Polish & Education and & Foreign Office; & Education, National \\
$\begin{array}{l}\text { Rectors' Conference } \\
\text { (43 HEIs }\end{array}$ & Research; Rectors & Federal Ministry of & Agency of Study \\
participating in Study & Conference; & Education and & Scholarships and \\
in Poland initiative) & Foundation & Science; the Länder; & Loans (Agentia de \\
& & German Research & Credite si Burse de \\
& & Foundation; & Studii); Other \\
& Humboldt & ministries and \\
& & Foundation, German & agencies \\
& & Rectors' Conference & implementing \\
& & & international \\
agreements
\end{tabular}

\subsection{Key Actors in Internationalisation Strategies and Practices}

We summarize in Table 5 (below) the situation with regard to the key actors in the four countries considered for the study. For the case of Germany and Estonia, as already mentioned above, we see a strong and coordinated presence of government actors. In Germany, the policy landscape is both very complex (both the federal government and the Länder have important prerogatives in higher education), and it also appears to be very mature and all coordinated. Special government agencies, such as DAAD and the German Research Foundation are very important, in fact they can be responsible in large part for "making a difference". We also note the active participation of the German Rectors' Conference. In terms of actors, the German model appears to be largely "governmental". We have not been able to clarify the extent to which non-governmental actors play a role, but they certainly exist (like the Humboldt Foundation). Most often, however, they appear to work in cooperation and even with the support of the government.

Estonia also appears to illustrate a governmental model, with the participations of HEIs' leaders (Rectors Conference). It is interesting to note the role of an intermediary organization, the Archimedes Foundation, which appears to have government support but benefits from the operational flexibility of an NGO. This model of some kind of "intermediary organizations" dedicated to supporting internationalisation strategy and efforts, is worth taking into account in countries like Romania, that consider now adopting internationalisation policies and building adequate support structures.

Poland is also an interesting case. The government is almost virtually absent but HEIs are mobilizing and developing their own institutional internationalisation strategies and working together to create a national strategic framework, as well as tools and instruments to support their needs and ambitions. Like in Estonia, we note the positive role of a NGO created with the specific purpose to assist HEIs, including, in this case, but not limited to, internationalisation. Unlike Estonia, this 
NGO appears to operate fully independently from the government with the support of member HEIs. The Polish case provides some support for the idea that, while the absence of government involvement may result in serious difficulties for any major internationalisation efforts, HEIs can organize themselves and find alternative partners to get things started, at least, and to reach a certain degree of success, rather that resigning themselves to inaction or to only following the often uncertain pushand-pull of international commitments made by the respective government that might have an impact on internationalisation.

The Romanian situation has already been explained, there are no key actors since there is no national strategy and no consistent national practices, except for those resulting from bilateral and international agreements (administered by ministries and state agencies). What is however important to note is the complete absence from the picture of the Romanian Rectors' Council. Of all four countries, Romania is the only one in which the organization of the leaders of HEIs play no role. In the context of our analysis in the present study, it appears that activating this organization is a good place to start, if not finding an alternative to it.

\subsection{Student Mobility Flows}

How can we try to answer the question "what works" and ("what doesn't")? what are good strategies, and good practices, in reality, beyond formal and normative models? The nature of our study does not allow providing any comprehensive, or even partial but definite, answer. Theoretically, one possible research strategy would be to look into student mobility fluxes and try to understand what is the differential impact of definite strategies and practices. Table 6 below provide data about student fluxes in the four countries, again insufficient for a decisive analysis. What we can see, however, is that Germany (with a comprehensive strategy and string support system) has the most international students. This is true not only in absolute numbers, as Germany stands out strikingly in terms of percentage of international students - well over $10 \%$, as opposed to about 2 or less than $2 \%$ in the other cases. Romania (lacking a national internationalisation strategy) has about the same percentage of international students as Estonia (with a well elaborated nationals strategy), and more than Poland (with significant bottom-up efforts and an informal strategy). Is this an indication that a national strategy doesn't necessarily make a difference? Difficult to say. We need to note that one country (Moldova) contribute half of Romania's number of international students, and students from Moldova are not exactly "international students". The numbers would be a lot worse if Moldova were factored out. Also, Romania has the lowest share of international students in the EU, in percentage terms, and the trend is decreasing numbers (UEFSCDI 2013). These facts, in turn, may speak for the need of a national strategy, or at least for the need of active and well articulated efforts at national level. The number of Romanian students studying aboard, on the other side, is increasing, and Romania is already a net exporter of students. If we consider 
the overall demographic trends in Romania, that is a decreasing population (overall student enrolment is already affected by these trends), the incapacity to attract significant number of international students may appear as an additional bad news. It is a fact that Romania used to be very attractive for international students during the communist times, although how to interpret this fact is not unambiguous. Perhaps this fact, however, is an indication of Romania's greater potential than its present performance. Certain areas, such as medicine (see Table 6, again) appear to have particularly promising potential. But as mentioned at the beginning of the study, internationalisation should not be conceived as being only about attracting (paying) international students. A good strategy for Romania should identify and consider other relevant factors and motivations as well.

Table 6 Student mobility flows data

\begin{tabular}{|c|c|c|c|c|}
\hline & Poland & Estonia & Germany & Romania \\
\hline $\begin{array}{l}\text { Percent of } \\
\text { students } \\
\text { enrolled } \\
\text { abroad } \\
(2010-2012)\end{array}$ & $2.2 \%$ & $7.7 \%$ & $4.8 \%$ & $\begin{array}{l}2.6 \% \\
\text { Increasing } \\
\text { trend; net } \\
\text { exporter }\end{array}$ \\
\hline $\begin{array}{l}\text { Incoming } \\
\text { foreign } \\
\text { students ( \% } \\
\text { of total } \\
\text { student } \\
\text { population, } \\
2010-2012 \text { ) }\end{array}$ & $\begin{array}{l}1.39 \% \\
24,253 \\
53 \% \text { from } \\
\text { neighbouring } \\
\text { countries (mostly } \\
\text { Ukraine, Belarus, } \\
\text { also Norway, } \\
\text { Sweden, Spain) } \\
13 \% \text { increase in } \\
2012 \text { compared } \\
\text { to } 2012 ; 100 \% \\
\text { from } 2005 / 6 \\
\text { One of lowest \% } \\
\text { in OECD }\end{array}$ & $\begin{array}{l}2.1 \% \\
1,900 \\
74 \% \text { from } \\
\text { neighbouring } \\
\text { countries: } \\
\text { Finland, Latvia, } \\
\text { the Russian } \\
\text { Federation or } \\
\text { Sweden }\end{array}$ & $\begin{array}{l}11.5 \% \\
\text { over 250,000 } \\
(13 \% \text { China, } \\
7 \% \text { Turkey, } 5 \% \\
\text { Russia) } \\
\text { 2000: 175,000; } \\
\text { 2011: over } \\
\text { 250,000, making } \\
\text { Germany the } \\
\text { fourth most } \\
\text { popular study } \\
\text { destination } \\
\text { worldwide. }\end{array}$ & $\begin{array}{l}1.98 \% \\
19,308 \\
(1.3 \% \text { in } 07 / \\
08 \\
\text { Moldova } \\
50 \% \text {, } \\
\text { Tunisia } \\
6.3 \% \text {, } \\
\text { Greece } 5 \% \text {, } \\
\text { Israel } 4.6 \%) \\
\text { Diminishing } \\
\text { numbers } \\
\text { and \%; } \\
\text { lowest shares } \\
\text { in EU }\end{array}$ \\
\hline $\begin{array}{l}\text { Most popular } \\
\text { programs } \\
\text { among } \\
\text { foreign } \\
\text { students }\end{array}$ & $\begin{array}{l}\text { Medicine } \\
\text { (including dentist } \\
\text { schools), } \\
\text { Management, } \\
\text { Economics, } \\
\text { International } \\
\text { Relations, } \\
\text { Philology, } \\
\text { Tourism }\end{array}$ & & & $\begin{array}{l}35 \% \\
\text { medical and } \\
\text { paramedical } \\
\text { studies in } \\
2007\end{array}$ \\
\hline
\end{tabular}

Data sources: Ferencz and Wächter 2007 — chapters on Germany and Romania; DAAD 2013a, b), UEFSCDI (2013). OECD (2013), Perspektywy Foundation (2013) and Archimedes Foundation (2013) for Poland and Estonia 


\subsection{Resources}

One last comparative zoom-in in this analysis is about resources mobilized in the respective countries in relation to their internationalisation strategies and activities.

In Estonia, separate funds are made available to support its internationalisation efforts, specifically the Doctoral Studies and Internationalisation Programme (DoRa) coordinated by the Archimedes Foundation, and they have grown since 2008, amounting to approximately EUR 32 million for the period 2008-2015 (http://www.kslll.net/PoliciesAndAchievements/ExampleDetails.cfm?id=131\#).

Like the other countries in this group, Estonia can also benefit from European funds in this area. The overall budget for DoRa programme comprises contributions allocated by the Ministry of Education and Research, $73 \%$ coming from the European Union Social Fund and $9 \%$ from the Estonian government as well as $18 \%$ share of the budget supported by individual HEIs participating in the programme (http://www.mapping-he.eu/Programmes/ProgramDetails.aspx? countryid= 8\&sm=1\&programid=P149).

The budget for this programme in 2008 was EUR 25,000 and it supported 400 grantees. In 2011, the budget reached over EUR 6.5 million and the number of grantees was 1200. (ibid). As part of the programme, Estonia offers scholarships for international students, mostly for $\mathrm{PhD}$ studies in a set of six fields of study including areas such as biotechnology, health, materials technology among others.

All of the strategies outlined in Germany are not only comprehensive and welldeveloped but they are also supported by significant resources. The DAAD's budget alone in 2011 was nearly EUR 400 million, with $45 \%$ funded by the Ministry of Foreign Affairs, $23 \%$ by the Federal Ministry of Education, and nearly $14 \%$ by the EU (DAAD: http://ec.europa.eu/research/iscp/pdf/daad_funding_ instruments_usa_germany.pdf).

Germany is unique in its approach to international students as it does not allow for charging higher tuition fees to international students, which is a common trend in the rest of Europe (British Council 2011). Overall, Germany seems to focus mostly on both the mutual understanding and on the skilled migration approaches based on the OECD typology.

Poland and Romania allocate resources from the national budgets for international student scholarships, but mainly for co-nationals from other countries, or for special target countries with particular historical, cultural, and ethnic ties (such as Moldova, in the case of Romania). In addition, in Poland, the HEIs participating in the "Study in Poland" programme, pay a fixed annual fee. In the academic year 2012-2013, the fee to participate in the programme and all of its aspects for an institution with over 15,000 students was roughly EUR 4,300 + VAT (18,000 PLN + VAT) (http://www. studyinpoland.pl/konsorcjum/index.php?option=com_content\&view=article\&id= 2580\&Itemid=4).

Both countries participate in the European mobility programs, benefiting from European funding. Universities in both countries have an unmistakable interest in fee paying international students. A study realized in Romania (UEFSCDI 2013) 
indicated not only that a national strategy and support infrastructure is missing, but universities have to face significant bureaucratic hurdles (approval from the central national authorities is needed) even when they recruit potential fee paying students through their own efforts.

\section{Conclusions: Lessons from a Comparison}

The comparison among the four countries was invited by the Romanian Executive Agency for Funding of Higher Education, Innovation and Development. The selection of countries was in a way arbitrary, reflecting the interests of the Agency. Still, the comparison appears to be quite informative, even to a surprising degree.

We have been able to identify four country profiles, with some overlapping elements. Also, we have been able to identify models, facts, and questions that would be useful to consider when Romanian stakeholders deliberate about the opportunity (necessity?) of a national approach (if not strategy) to internationalisation of higher education, about conceptual and operational aspects related to such a future approach or strategy.

In terms of country profiles, we propose the following summary:

- Germany offers an example that is close to a kind of ideal normative model, promoted by the EC and by other authoritative international actors. This model includes: a comprehensive strategy not limited to recruitment of international students, formalized in a series of public documents. Non-governmental actors are present, but governmental actors (both national and region level) are in the driving seat, assuming responsibility for internationalisation strategy and practices, providing direction, resources, policy and administrative support; the strategy is well coordinated within the sector and across sectors; it is coordinated across several layers of policy making and implementation; higher education institutions play a major role, not individually, but through the Rectors' Conference. Finally, this model appears to work (whether it can be exported as such, is a question). It allows to meet major objectives of national, state, and sectoral relevance, including relevance for higher education.

- Estonia is an example of a small country committed to developing and implementing a formal, well-articulated strategy, adapted to national conditions; this strategy is focused, rather than all-encompassing (like in Germany), it involves narrower "strategic choices"; the strategy is also coordinated within the sector and with other sectors, and among the relevant policy layers and actors; coordination among actors involves not only technical or strategic matters, but also ethic aspects in internationalisation (a local innovation); universities participate and play a key role through the Rectors Conference; as another local innovation, a flexible organisation was created specifically to support internationalisation efforts in Estonia, which combines state support, with NGO operational flexibility. It is still early to say whether this model works, or at least we have not been 
able to access data that would allow an evaluation, which would be a very important exercise, as the model seems to be very promising. Many of its elements appear to be "transportable" to other countries, but any immediate import should be considered with care, in particular in the absence of impact evaluation.

- Poland is yet a different example, a different country profile. Internationalisation efforts are bottom-up, initiated by HEIs; they have even developed a kind of informal strategy; government authorities are largely absent, and their absence does not seem to help universities in their efforts; universities coming together created new instruments; a special structure was created, a foundation, similar but not identical with that from Estonia, as it appears to be a genuine non-governmental initiative and operation in Poland; universities have been able to identify alternative partners (local authorities). There is no proper assessment of this "model" either. On the positive side, the Polish example shows that universities can act whether the government is absent, and with some good results. What is unclear is whether the significant non-participation of the government is an insurmountable obstacle or not.

- Romania has a limited record of activities in internationalisation; it lacks a national strategy and significant practices, except for "following", based on international agreements and except for the special relationship with Moldova; the advantage is that, starting almost form zero, it has a chance to "get it right" quickly.

It is difficult to find arguments against the development of a national internationalisation strategy for Romania. Rather, the real question is how to develop and implement one. This "question" comprises in fact several "questions". The present study offers certain suggestions regarding what these exact questions might be, and how to approach them. For example:

- Is it an option not to have a national internationalisation strategy? Yes, but it will probably come at a cost. Also, coordination at national level seems required anyway. In absence of an active involvement of the government in this regard, an alternative agent seems to be needed to coordinate efforts on the national level - for example a non-governmental organisation, active Rectors' Conference, or a university association.

- Is it the case that government has the key responsibility in internationalisation? Probably yes, and it must assume it.

- If governmental inaction persists, is it possible to overcome such a situation? Possibly, but very hard to accomplish, through a mobilisation of universities and alternative partners. Universities must activate themselves in any case. Action by the Romanian Rectors Council is a must in any case.

- How to decide on priorities? There are some good examples in Europe (and there must be some domestic expertise available as well).

- Is there any one-model that Romania could just import and put in practice as such? Most likely no, but there are good lessons to be learn from selective other exercises. For example, there is clear merit in cross-sectoral coordination of an internationalisation strategy. 
- How detailed should such a strategy be? Should it go to the level of detail as in Estonia indicating specific fields of study that are more 'desired' and specific 'target countries', or being too top-down would not allow enough flexibility for the institutional implementation? We believe a Romanian strategy could build on some of the existing individual HEIs efforts to date, and effectively combine broader national goals with elements that are more attractive for individual institutions, to ensure effective implementation. It might not be possible to opt out from the revenue-generating approach, but it should not be the exclusive focus for the long run.

Open Access This chapter is distributed under the terms of the Creative Commons Attribution Noncommercial License, which permits any noncommercial use, distribution, and reproduction in any medium, provided the original author(s) and source are credited.

\section{References}

Agreement on Good Practice in the Internationalisation of Estonia's Higher Education Institutions. (2007). Study in Estonia. Available at: http://www.studyinestonia.ee/images/tekstid/ headetavadelepe.pdf.

Altbach, P. G., \& Knight, J. (2007). The Internationalization of higher education: Motivations and realities. Journal of Studies in International Education 11(3/4 Fall/Winter), 290-305.

Becker, R., \& Kolster, R. (2012). International student recruitment: policies and development in selected countries. The Hague: Nuffic. Accessed online at: http://www.nuffic.nl/en/library/ international-student-recruitment.pdf.

British Council. (2011). Global gauge. Education Intelligence Report Series.

Committee and the Committee of the Regions. Supporting growth and jobs -an agenda for the modernisation of Europe's higher education systems.

DAAD. (2013a). Facts and figures on the International Nature of Studies and Research in Germany. Wischenschaft weltoffen. Bielefeld: Bertselmann Verlag.

DAAD. (2013b). Strategy 2020. Available online at: https://www.daad.de/portrait/presse/ pressemitteilungen/2013/Strategie2020.

De Wit, H. (2010). Internationalisation of higher education in Europe and its assessment, trends and issues. NVAO Nederlands-Vlaamse Accreditatieorganisatie.

EC-Commission of the European Communities. (2003). Communication from the Commission The role of universities in the Europe of Knowledge.

EC - European Commission. (2013). Communication from the Commission to the European Parliament, the Council, the European Economic and Social Committee and the Committee of the Regions. European higher education in the world.

EC -Commission of the European Communities. (2005). Communication from the Commission Mobilising the brainpower of Europe: Enabling universities to make their full contribution to the Lisbon Strategy.

EC -Commission of the European Communities. (2006). Communication from the Commission to the Council and the European Parliament. Delivering on the modernisation agenda for Universities: Education, Research, and Innovation.

EC -European Commission. (2011). Communication from the Commission to the European Parliament, the Council, the European and Economic and Social.

Estonian Ministry of Education and Research. (2006). Strategy for the internationalisation of Estonian higher education over the Is 2006-2015. Access from: http://www.studyinestonia.ee/ about-us/higher-education-in-estonia/strategy-documents. 
Estonian Parliament. (2006). Estonian higher education strategy, 2006-2015. Retrieved from: http://www.studyinestonia.ee/about-us/higher-education-in-estonia/strategy-documents.

Estonian Ministry of Education and Research. (2007). Knowledge-based Estonia. Estonian Research and development and innovation strategy 2007-2013. Tartu.

European University Association (EUA). (2013). Internationalisation in European higher education: European policies, institutional strategies and EUA support. European University Association asbl: Brussels.

Federal Ministry of Education and Research. (2008). Strengthening Germany's role in the global knowledge society. Strategy of the Federal Government for the Internationalization of Science and Research. Available online at: http://www.bmbf.de/pubRD/InternationalisierungsstrategieEnglish.pdf.

Federal Ministry of Education and Research. (2013). Strategy of the Federal and Länder Ministers of Science for the internationalisation of the higher education institutions in Germany. Resolution of the 18th Meeting of the Joint Science Conference in Berlin on 12 April 2013. Available at: http://www.bmbf.de/pubRD/Internationalisierungsstrategie_engl.Fassung.pdf.

Ferencz, I., \& Wächter, B. (Eds.), (2012). European and national policies for academic mobility. Linking rhetoric, practice, and mobility trends. ACA Papers in International Cooperation and Education. Bonn: Lemmens.

http://www.studyinpoland.pl/konsorcjum/index.php?option=com_content\&view=article $\&$ id= 2580\&Itemid $=4$.

http://ec.europa.eu/research/iscp/pdf/daad_funding_instruments_usa_germany.pdf.

(http://www.mapping-he.eu/Programmes/ProgramDetails.aspx ?countryid=8\&sm=1\&programid= P149).

ICEF Monitor. (2013) How Estonia established its international education brand. Published on 7 November 2013. Available online at: (http://monitor.icef.com/2013/11/how-estoniaestablished-its-international-education-brand/.

Kehm, B. M. (2003). Internationalisation in higher education: From regional to global. In R. Begg (Ed.), The dialogue between higher education research and practice (pp. 109-119). The Netherlands: Kluwer Academic Publishers.

Kehm, B. M. \& Teichler, U. (2007). Research on internationalisation in higher education. Journal of Studies in International Education, 11(3/4 Fall/Winter): 260-273.

Knight, J. (1999). Issues and trends in internationalization: A comparative perspective. In S.L. Bond \& J.P. Lemasson (Eds.), A new world of knowledge. Canadian Universities and Globalization (pp. 201-238). Ottawa: International Development Research Centre.

Ministry of Interior of Poland. (2013). Polityka Migracyjna Polski - stan obecny i postulowane dzialania ("Migration policy of Poland - the current state of play and the further actions"). Warsaw: Migration Policy Department.

OECD - Organisation for Economic Co-operation and Development. (2004) Trade in higher education: Opportunities and challenges. Paris: Author.

OECD - Organisation for Economic Co-operation and Development. (2013). Education at a glance 2013. Paris: OECD.

Poland's Migration Policy. (2012). Original title of the document in Polish: Polityka Migracyjna Polski - stan obecny i postulowane dzialania. Dokument przyjęty przez Radę Ministrów w dniu 31 lipca 2012 r. Accessed online at: http://PMP_przyjeta_przez_Rade_Ministrow_31_ lipca_2012_2_.pdf.

Siwinska, B. (2009) The problems of internationalization in Poland. International higher education, 55(Spring 2009), 11-12.

Siwinski, W. (2013). Ilu studentow zagranicznych potrzebuje Polska? (How many international students does Poland need?). Presentation at conference: Studenci Zagraniczni w Polsce 2013 (International Students in Poland 2013); 17-18 January 2013; Warsaw, Poland. Available at: http://www.studyinpoland.pl/konsorcjum/pdfy/konferencja2013/1/ilu_studentow_ zagranicznych.pdf.

Teichler, U. (2007) Die Internationalisierung der Hochschulen: Neue forderungen and Strategien. Frankfurt, Main: Campus. 
Teichler, U. (2012). International student mobility in the context of the Bologna process. Journal of International Education and Leadership, 2, 1.

UEFISCDI -The Executive Agency for Higher Education, Research, Development and Innovation Funding. (2013). Internationalisation of Higher Education in Romania. Bucharest. 